\title{
Russia's black carbon emissions: focus on diesel sources
}

\author{
Nazar Kholod ${ }^{1}$, Meredydd Evans ${ }^{1}$, and Teresa Kuklinski ${ }^{2}$ \\ ${ }^{1}$ Joint Global Change Research Institute, Pacific Northwest National Laboratory, 5825 University Research Court, \\ Suite 3500, College Park, MD 20740, USA \\ ${ }^{2}$ US Environmental Protection Agency, Office of International and Tribal Affairs, 1200 Pennsylvania Ave., \\ NW, Washington, DC 20460, USA
}

Correspondence to: N. Kholod (nazar.kholod@pnnl.gov)

Received: 5 June 2016 - Published in Atmos. Chem. Phys. Discuss.: 16 June 2016

Revised: 22 August 2016 - Accepted: 27 August 2016 - Published: 12 September 2016

\begin{abstract}
Black carbon (BC) is a significant climate forcer with a particularly pronounced forcing effect in polar regions such as the Russian Arctic. Diesel combustion is a major global source of BC emissions, accounting for $25-30 \%$ of all $\mathrm{BC}$ emissions. While the demand for diesel is growing in Russia, the country's diesel emissions are poorly understood. This paper presents a detailed inventory of Russian BC emissions from diesel sources. Drawing on a complete Russian vehicle registry with detailed information about vehicle types and emission standards, this paper analyzes BC emissions from diesel on-road vehicles. We use the COPERT emission model (COmputer Programme to calculate Emissions from Road Transport) with Russia-specific emission factors for all types of on-road vehicles. On-road diesel vehicles emitted $21 \mathrm{Gg}$ of BC in 2014: heavy-duty trucks account for $60 \%$ of the on-road $\mathrm{BC}$ emissions, while cars represent only $5 \%$ (light commercial vehicles and buses account for the remainder). Using Russian activity data and fuel-based emission factors, the paper also presents $\mathrm{BC}$ emissions from diesel locomotives and ships, off-road engines in industry, construction and agriculture, and generators. The study also factors in the role of superemitters in $\mathrm{BC}$ emissions from diesel on-road vehicles and off-road sources. The total emissions from diesel sources in Russia are estimated to be $49 \mathrm{Gg}$ of $\mathrm{BC}$ and $17 \mathrm{Gg}$ of organic carbon (OC) in 2014. Off-road diesel sources emitted $58 \%$ of all diesel BC in Russia.
\end{abstract}

\section{Introduction}

Black carbon (BC), a component of particulate matter (PM), may be the most powerful contributor to climate change after carbon dioxide (Bond and Sun, 2005; Bond et al., 2013). $\mathrm{BC}$ emissions cause significant warming effects through direct light absorption, interaction with clouds, and reduced albedo on snow. In polar regions especially, BC plays an important role because $\mathrm{BC}$ accumulation on snow and ice facilitates the absorption of solar radiation, increases air temperature, and accelerates snow and ice melting (Warren and Wiscombe, 1980; Hansen and Nazarenko, 2003; Quinn et al., 2008, 2011; Koch and Del Genio, 2010; Bond et al., 2013).

$\mathrm{BC}$, as a major component of diesel PM, also has adverse health impacts (WHO, 2012). Chronic exposure to PM is associated with a range of diseases and can cause premature death from cardiopulmonary disease and lung cancer (Pope et al., 2011). Exposure to PM emissions is the ninth-leading factor of premature death globally; the World Health Organization estimates that PM pollution accounted for 3.1 million deaths in 2010 (WHO, 2013). According to the Global Burden of Disease study, ambient PM pollution caused more than 100000 premature deaths in Russia in 2013 (GBD, 2016).

$\mathrm{BC}$ is a product of incomplete combustion of fossil fuels, biofuels, and biomass. In 2000, diesel BC emissions accounted for $25-30 \%$ of all energy-related BC emissions worldwide (Bond et al., 2013). In Europe, North America, and Latin America, diesel transport, both on- and off-road, accounts for about $70 \%$ of all energy-related $\mathrm{BC}$ emissions. Over the past decade, diesel production in Russia has risen by $10 \%$ (Minenergo, 2015). Diesel is important to BC for 
two additional reasons. First, diesel combustion results in a high share of $\mathrm{BC}$ compared with other emissions sources. Second, there are well-established control technologies and policies to reduce emissions from diesel combustion. In fact, this study finds that Russian emissions are lower than many previous studies have shown specifically because we are able to account for the impact of the emission standards in reducing emissions.

Inventories are important in developing mitigation policies and improving our understanding of global climate in models. Global or regional emission inventories, however, tend to rely on simple assumptions for emission calculations because country-level data might not be available. The aim of this paper is to present a detailed BC emission inventory from diesel sources in the Russian Federation for the base year 2014. Russia is the second-largest producer of crude oil in the world (IEA, 2015a); likewise, it is a large producer and consumer of diesel fuel. Despite the large diesel consumption of Russia, the country has historically represented a significant gap in our global understanding of BC emissions. Previous studies reporting BC emissions from Russian diesel sources were estimated primarily by combining fuel consumption with fuel-based emission factors. This paper instead draws on detailed data about the Russian vehicle fleet, annual mileage by vehicle category, the usage of emission controls on off-road vehicles, and other factors such as the existence of superemitters. This study focuses on BC emissions from diesel sources only per the parameters of the United States Environmental Protection Agency's (US EPA) Reduction of Black Carbon from Diesel Sources in the Russian Arctic project, which is part of the USG Arctic Black Carbon Initiative (EPA, 2016).

\section{Methodology}

\subsection{Emission standards for diesel engines}

Russia has adopted the vehicle emission standards developed by the United Nations Economic Commission for Europe (UNECE). Specifically, Russia introduced Euro 2 standards in 2006 (Supplement Table S1). Emission standards in Russia apply to both domestically produced and imported vehicles. The minimum emission standard in 2014 was Euro 4 for cars and Euro IV for trucks and buses. As of January 2016, the minimum standard is Euro 5/Euro V. Russia has no official plans to move to the Euro 6 standard.

Russia has also adopted the European standard for PM emissions for off-road vehicles used for agriculture and forestry (these off-road standards are broken into "stages" in the European system). According to Technical Regulation 031/2012, agricultural and forestry off-road vehicles should meet the UNECE standard (Stage III) (Eurasian Commission, 2012). However, in the baseline year for this inventory (2014), there was no PM emission standard for agricul- tural vehicles in Russia. Additionally, the implementation of this new standard appears to be weak. Apart from agriculture and forestry, equipment in other sectors in Russia is not obliged to comply with any PM emission standards (Eurasian Commission, 2011b).

\subsection{Methodology for emission calculations from on-road vehicles}

The European COPERT model (COmputer Programme to calculate Emissions from Road Transport) calculates emissions from on-road vehicles. The European Environmental Agency (EEA) supported the development of COPERT. EEA member countries use this free software for official road transport emission inventory preparation (Emisia, 2015). Twenty-two countries of the European Union use the model to calculate road transport emissions (Ntziachristos et al., 2009). In this study, we use the COPERT 4 model (version 11.3).

Diesel vehicles in the COPERT model are classified into four large groups: passenger cars, light commercial vehicles (LCVs), heavy-duty trucks, and buses. In the model, exhaust $\mathrm{BC}$ emissions from vehicles depend primarily on the following: (1) the number of vehicles on the roads, (2) emission factors, and (3) average number of kilometers traveled. The COPERT model uses Europe-specific emission factors and allows users to input country-specific emissions factors. The Russian Scientific Research Institute for Automobile and Transportation (NIIAT) developed two methodologies for calculating emissions from on-road transport (NIIAT, 2006, 2012). They are based on the simplified European Monitoring and Evaluation Programme (EMEP)/Core Inventory of Air Emissions (CORINAIR) approach (now called EMEP/EEA Air Pollutant Emission Inventory Guidebook).

NIIAT has developed PM emission factors for Russian vehicles based on vehicle emission test data for both Russian and foreign vehicles. Based on vehicle driving tests conducted at the Testing Centre for Motor Vehicles, Spare Parts and Accessories, NIIAT has developed emission factors for Russian models. For foreign-made vehicles, NIIAT relies on data from the European EMEP/CORINAIR guidebook. Thus, Russia-specific emission factors for $\mathrm{PM}_{2.5}$ in the NIIAT methodologies are based on the average for every vehicle type and emission class on Russian roads. Supplement Table S2 provides the emission factors for the following categories of diesel vehicles: cars, light trucks and buses (LCVs), heavy-duty trucks, and buses on three types of roads (urban, rural, and highways).

We derive $\mathrm{BC}$ / PM ratios from the EEA emission guidebook (EEA, 2013). The COPERT model can also directly calculate emissions of elemental carbon (EC) and organic carbon (OC). In European emission studies, EC is assumed to be equal to $\mathrm{BC}$ for transport due to the nature of the combustion processes. 
Table 1. $\mathrm{PM}_{2.5}$ emission factors and $\mathrm{BC} / \mathrm{PM}$ ratios for off-road diesel sources.

\begin{tabular}{|c|c|c|c|c|c|}
\hline Sector & Emission controls & $\mathrm{PM}_{2.5}, \mathrm{~g} \mathrm{~kg}^{-1}$ & Source & $\mathrm{BC} / \mathrm{PM}_{2.5}$ ratio & Source \\
\hline Diesel generators & No control & 6.0 & Bond et al. (2004) & 0.66 & Bond et al. (2004) \\
\hline Heat plants & No control & 0.25 & Bond et al. (2004) & 0.29 & Bond et al. (2004) \\
\hline \multirow{3}{*}{$\begin{array}{l}\text { Industry } \\
\text { (stationary } \\
\text { engines) }\end{array}$} & No control & 4.308 & $\begin{array}{l}\text { EEA (2013), } \\
\text { 1.A.4., Table 3-2 }\end{array}$ & 0.55 & $\begin{array}{l}\text { EEA (2013), } \\
\text { 1.A.4., Table D3 }\end{array}$ \\
\hline & 1991 - Stage I & 3.551 & $\begin{array}{l}\text { EEA (2013), } \\
\text { 1.A.4., Table 3-2 }\end{array}$ & 0.55 & $\begin{array}{l}\text { EEA (2013), } \\
\text { 1.A.4., Table D3 }\end{array}$ \\
\hline & Stage II & 1.031 & $\begin{array}{l}\text { EEA (2013), } \\
\text { 1.A.4., Table 3-2 }\end{array}$ & 0.80 & $\begin{array}{l}\text { EEA (2013), } \\
\text { 1.A.4., Table D3 }\end{array}$ \\
\hline \multirow[t]{2}{*}{ Construction } & No control & 4.308 & $\begin{array}{l}\text { EEA (2013), } \\
\text { 1.A.4., Table 3-2 }\end{array}$ & 0.55 & $\begin{array}{l}\text { EEA (2013), } \\
\text { 1.A.4., Table D3 }\end{array}$ \\
\hline & 1991 - Stage I & 3.551 & $\begin{array}{l}\text { EEA (2013), } \\
\text { 1.A.4., Table 3-2 }\end{array}$ & 0.55 & $\begin{array}{l}\text { EEA (2013), } \\
\text { 1.A.4., Table D3 }\end{array}$ \\
\hline Rail & No control & 4.62 & Yan et al. (2014) & 0.65 & $\begin{array}{l}\text { EEA (2013), } \\
\text { 1.A.3.c.,Table A.1 }\end{array}$ \\
\hline Ships & No control & 1.4 & $\begin{array}{l}\text { EEA (2013), } \\
\text { 1.A.3.d., Table 3-2 }\end{array}$ & 0.31 & $\begin{array}{l}\text { EEA (2013) } \\
\text { 1.A.3.d., Table 3-2 }\end{array}$ \\
\hline \multirow[t]{4}{*}{ Agriculture } & No control & 3.755 & $\begin{array}{l}\text { EEA (2013), } \\
\text { 1.A.4.c.ii, Table 3-2 }\end{array}$ & 0.55 & $\begin{array}{l}\text { EEA (2013), } \\
\text { 1.A.4.c ii, Table D3 }\end{array}$ \\
\hline & 1991 - Stage I & 1.644 & $\begin{array}{l}\text { EEA (2013), } \\
\text { 1.A.4.c ii, Table 3-2 }\end{array}$ & 0.54 & $\begin{array}{l}\text { EEA (2013), } \\
\text { 1.A.4.c ii, Table D3 }\end{array}$ \\
\hline & Stage I & 0.832 & $\begin{array}{l}\text { EEA (2013), } \\
\text { 1.A.4.c ii, Table 3-2 }\end{array}$ & 0.79 & $\begin{array}{l}\text { EEA (2013), } \\
\text { 1.A.4.c ii, Table D3 }\end{array}$ \\
\hline & Stage II & 0.627 & $\begin{array}{l}\text { EEA (2013), } \\
\text { 1.A.4.c ii, Table 3-2 }\end{array}$ & 0.77 & $\begin{array}{l}\text { EEA (2013), } \\
\text { 1.A.4.c ii, Table D3 }\end{array}$ \\
\hline
\end{tabular}

Diesel engines emit BC emissions in two distinct stages of operations - cold start and hot operation. The COPERT and the NIIAT models use different approaches to calculate cold-start emissions. However, in their study of BC emissions from diesel vehicles in the Murmansk region, Evans et al. (2015) showed that both methodologies yield very similar total emissions (Evans et al., 2015). As a result, in this study we do not analyze hot and cold emissions separately and present only the total emissions.

\subsection{Methodology for emission calculations from off-road engines}

$\mathrm{BC}$ emission calculations from off-road diesel engines can be expressed by Eq. (1):

$$
\begin{aligned}
\mathrm{BC} \text { emissions }= & \text { fuel }(\mathrm{kg}) \times \mathrm{PM} \text { emission factor }\left(\mathrm{g} \mathrm{kg}^{-1}\right) \\
& \times \mathrm{BC} / \mathrm{PM} \text { ratio. }
\end{aligned}
$$

We used Eq. (1) to calculate emissions from off-road sources listed in Sect. 5. Table 1 presents PM emission factors and BC / PM speciation ratios used in this study. Though emission factors reported in the literature could be different from those in the emission guidebook, we use the EEA emission factors for consistency. The advantage of using this approach is that the guidebook reports emission factors for equipment without emission controls. Since the majority of diesel off-road vehicles and equipment are old and Russia does not regulate particulates from off-road diesel sources, we assumed that there are no emission controls on most of the off-road diesel sources. Some small percentage of imported engines might have emission controls.

\section{Fuel data}

\subsection{Production of diesel fuel}

The Russian Federation is the second-largest producer of crude oil in the world, producing $13 \%$ of total world oil in 2014 (IEA, 2015a). It is a large producer of diesel fuel as well. The country increased diesel production from 70 million $t$ (Mt) in 2010 to $77 \mathrm{Mt}$ in 2014. Importantly, over the same time frame, Russia implemented standards that improved the quality of its diesel fuel, reducing sulfur content (Fig. 1). Sulfur content of diesel fuel is an important factor in emission reductions. Diesel with high-sulfur content (measured in parts per million, or ppm) can destroy emission control devices, such as particulate filters. Availability of lowsulfur diesel is an important prerequisite for the introduction of more stringent vehicle emission standards.

The share of Euro 5 diesel (with sulfur content of $10 \mathrm{ppm}$, otherwise known as ultralow-sulfur fuel) increased from $6 \%$ in 2011 to $50 \%$ in 2014 (Fedstat, 2015c). By the end of 2015, according to an estimate of the Russian Ministry of Energy, 


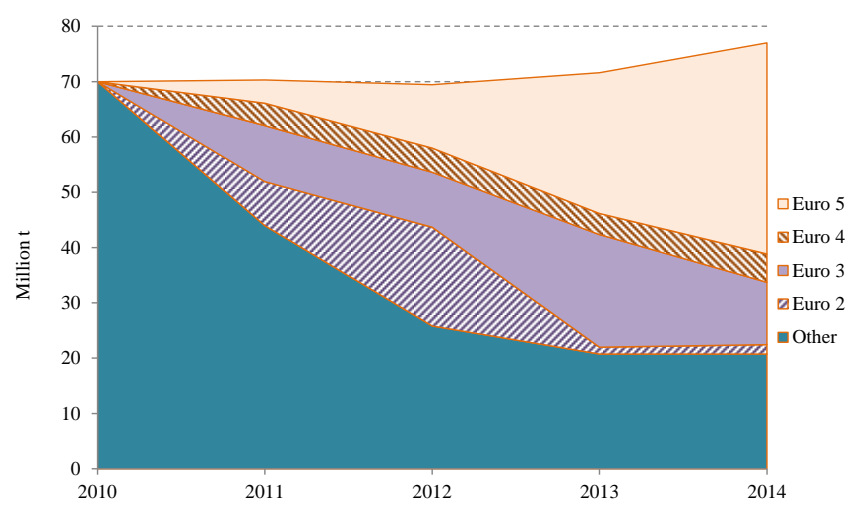

Figure 1. Production of diesel fuel by Euro class in Russia, 20102014, in units of Mt. Source: Fedstat (2015c).

Euro 5 diesel accounted for $82 \%$ of the total diesel production (Government of Russian Federation, 2015). Russia exports more than half of diesel produced; the quality of exported diesel is lower than that of the diesel used domestically. Russia banned the domestic sale of lower-grade diesel in 2013. In 2014, only Euro 4 (50 ppm) and Euro 5 (10 ppm) fuels were legal to sell for on-road transport (Eurasian Commission, 2011a). However, compliance with this standard is not universal. Rosstandard, a government agency responsible for fuel quality control, found that the sulfur content exceeded the maximum allowable content in $21 \%$ of the fueling stations checked in 2014 (Rosstandard, 2015). Though Russia banned high-sulfur diesel, the demand for cheap diesel remains because older engines, especially offroad vehicles, can save money by using high-sulfur diesel.

\subsection{Diesel consumption}

According to the Russian Ministry of Energy, Russia's domestic diesel supply was $32 \mathrm{Mt}$ in 2014 (Minenergo, 2015). Euro 4 and Euro 5 diesel accounted for $88 \%$ (28 Mt) of the domestic diesel supply in 2014, which is more than enough to fuel all the Euro 4 and Euro 5 vehicles. In other words, fuel quality alone likely does not impact emissions.

On-road transport is the largest consumer of diesel, but estimates vary. There are several data sources on diesel consumption by on-road transport, including official statistics, officially commissioned fuel balances, data from international organizations, and bottom-up estimates.

The Russian fuel consumption statistics are based to a large extent on reports from enterprises. Only medium and large enterprises must report their fuel use to the Federal State Statistics Service (Fedstat). Large companies must complete the so-called TER 4 form on fuel consumption "Fuels and energy inventory, inflow, consumption, and balance at the end of the reporting period". The aggregated data are publicly available (Fedstat, 2015e, h). Another data source is the TER 11 form on fuel consumption by unit of produc- tion; however, this information is not available for all sectors. Small businesses are not required to submit this information, yet they employ 11 million people (Fedstat, 2015b, d, f, g) and produce more than $20 \%$ of goods and services (GKS, 2015a). Neither is there official information on diesel consumption by vehicles owned by individuals (for example, on diesel sold at fueling stations). As a result, the official data on diesel consumption by on-road vehicles are incomplete. However, large enterprises do not need to conduct surveys to analyze their sales, so the diesel data likely underreport diesel consumption by individuals and small enterprises. According to Fedstat, vehicles owned by medium and large enterprises consumed 12.7 Mt of diesel in 2013 and 12.2 Mt in 2014 (Fedstat, 2015h). The International Energy Agency (IEA) reports that Russia's on-road transport consumed $11.2 \mathrm{Mt}$ of diesel in 2013 (IEA, 2015b). Both assessments likely underestimate the diesel consumption by on-road vehicles in the country.

There are several independent bottom-up estimates of diesel consumption by on-road transport. The Russian research company Petromarket estimated that on-road vehicles consumed 23.5 Mt of diesel in 2013 and 24.5 Mt in 2014 . Analytical agency Avtostat calculated that on-road vehicles consumed 25.8 Mt of diesel in 2014 (Avtostat, 2015b). Avtostat also estimated that vehicles in the European part of the Russian Federation consumed $70 \%$ of fuel used by on-road transport. However, their assessments both have their limitations because they do not use a fuel balance approach; in other words they do not match diesel consumption by onroad vehicles and off-road engines with the production of diesel fuel in the country.

In this paper, we use data from the Russian Center for Energy Efficiency (CENEf), which uses a balance approach for assessing the fuel consumption. CENEf is a leading Russian energy research organization commissioned by the Ministry of Energy to develop fuel balances. It has access to multiple types of fuel statistics and uses a sophisticated transport model to calculate fuel consumption by on-road vehicles. CENEf prepares the Russian energy balances by integrating the reporting forms from medium and large enterprises and bottom-up calculations to cross-check allocations across sectors. CENEf also ensures that supply of crude oil and oil products balances demand. Table 2 shows the diesel consumption in 2014 (in thousand metric tons, kt). CENEf estimated that the total diesel consumption in the country was about $32 \mathrm{Mt}$ in 2014. On-road vehicles used 22.2 Mt of the final diesel consumption. Other significant consumers of diesel are rail, diesel generators and boilers, industry, and agriculture.

We did not attempt to estimate the military fuel consumption. Military might be a large consumer of diesel in the country; however, none of the Russian experts were able to provide fuel estimates. We might assume that military consumption is spread throughout all sectors, but we cannot verify this assumption. We should note that the military 
Table 2. Diesel consumption by sector in $2014(\mathrm{kt})$.

\begin{tabular}{lrr}
\hline Diesel consumption & 2013 & 2014 \\
\hline Domestic supply & 30350 & 31991 \\
Transformation processes & 1211 & 1349 \\
Electricity plants & 945 & 1034 \\
Heat plants & 266 & 315 \\
Energy industry own & 173 & 236 \\
use (coal, oil, gas) & & \\
Final consumption & 28966 & 30406 \\
Industry & 2785 & 3279 \\
Mining & 1281 & 1509 \\
Other industry & 1504 & 1771 \\
Construction & 438 & 414 \\
Transport & 23993 & 24970 \\
Rail & 2337 & 2261 \\
Road & 21066 & 22189 \\
Domestic navigation & 423 & 372 \\
Other transport & 167 & 148 \\
Agriculture and fishing & 1749 & 1711 \\
Agriculture & 1592 & 1557 \\
Fishing & 157 & 154 \\
Other & 31 & 32 \\
\hline
\end{tabular}

Source: I. Bashmakov, personal communication, 2016. Note Domestic supply includes all energy resources used in the country. Transformation processes comprise the conversion of primary forms of energy to secondary (e.g., crude oil to oil products or coal to electricity). Final consumption equals the sum of the consumption in the end-use sectors.

uses diesel with high-sulfur content. Most of the military equipment is designed for high-sulfur fuel; Russia prohibits low-sulfur diesel for military goals. From 1 January 2015, the intergovernmental standard GOST 305-2013 requires the 2000 ppm sulfur content for the defense orders (Rosstandard, 2013).

\section{On-road transportation}

\subsection{Activity data}

\subsubsection{Registered fleet}

We use the complete vehicle registry containing information from about 49 million records to analyze on-road transport in Russia. The Russian analytical agency Avtostat provided the official registry with detailed vehicle information on fuel type and emission standard (Avtostat, 2015c). According to Avtostat data, 40.83 million passenger cars were registered in Russia as of January 2015. The share of diesel passenger cars was $4.2 \%$ (Avtostat, 2015c). The popularity of diesel cars is growing in Russia, representing $7-8 \%$ of new sales. Only $2 \%$ out of the 1.7 million diesel cars registered in Russia in 2014 were Russian models. All other diesel cars were imported or produced in Russia by foreign companies. Among the 3.96 million LCVs registered in 2014, $28 \%$ used diesel. The share of diesel LCVs in new sales is also growing, and every other LCV sold in Russia is equipped with a diesel engine. The heavy-duty truck fleet consists of 3.73 million vehicles. There were 2.32 million diesel trucks ( $62 \%$ of the truck fleet) registered in 2014. The fact that not all heavyduty trucks use diesel plays an important role in emission calculations. Studies that assume that all heavy-duty trucks use diesel tend to overestimate their emissions. In recent years, $98 \%$ of new trucks run on diesel. Russian-make heavy-duty trucks constitute about two-thirds of the diesel truck fleet. We grouped all diesel trucks into four groups depending on their weight: < $7.5 \mathrm{t}$ (35\% of the truck fleet), 7.5-12t (19\%), 12 $14 \mathrm{t}(9 \%)$, and above $14 \mathrm{t}$ (37\%) (RAMR, 2012). This classification is consistent with the COPERT and NIIAT models. There were 0.39 million buses registered in Russia in 2014. Forty-five percent of buses run on diesel. Russian brands made up about two-thirds of the diesel bus fleet. We grouped all diesel buses into three groups depending on their size: small buses ( $75 \%$ of the bus fleet), medium $(12 \%)$, and large and extra-large $(13 \%)$.

\subsubsection{Active vehicles}

Russian experts point out that the official vehicle registry does not correctly reflect the number of vehicles on the roads (Donchenko, 2013; Donchenko et al., 2016; Avtostat, 2016, 2015a). A significant share of the fleet is very old: $28 \%$ of cars and $49 \%$ of LCVs are older than 10 years, and $36 \%$ of trucks and $23 \%$ of buses are older than 20 years (Avtostat, 2015c). The fact that these vehicles are still registered does not mean that they are in working condition. For emission calculations we assess the "active fleet", that is, the vehicles that are used regularly. To estimate the share of active vehicles, Avtostat used annual data from the Russian Union of Insurers about the number of insurance policies (stickers) issued. The total number of stickers issued is a good proxy for the active fleet because it is illegal to use vehicles without insurance stickers. According to Avtostat estimates, the share of active passenger cars is $76 \%$ of the number of registered cars; for LCVs, buses, and trucks these shares are 80, 49, and $64 \%$, respectively. Using the age distribution of diesel and gasoline vehicles, we calculated the share of active vehicles in the diesel and gasoline fleets. Table 3 shows the summary of our calculations. Supplement Table S3 shows the number of active diesel vehicles by type and emission standard in Russia in 2014.

\subsubsection{Distribution by emission standard}

Emission standards and fleet upgrades play an important role in emission reductions. For example, NIIAT estimated that from 2006, when Russia first had introduced emission standards, to $2011 \mathrm{PM}$ emissions from on-road vehicles in the country dropped by $30 \%$ (Donchenko, 2007, 2013). This occurred even as the number of registered trucks and cars 
Table 3. Percentage of active diesel and gasoline vehicles.

\begin{tabular}{lrrr}
\hline & $\begin{array}{r}\text { Share of all active } \\
\text { vehicles (Avtostat) }\end{array}$ & $\begin{array}{r}\text { Share of active diesel } \\
\text { vehicles (calculated) }\end{array}$ & $\begin{array}{r}\text { Share of active gasoline } \\
\text { vehicles (calculated) }\end{array}$ \\
\hline Cars & $76 \%$ & $86 \%$ & $75 \%$ \\
LCVs & $80 \%$ & $84 \%$ & $67 \%$ \\
Trucks & $49 \%$ & $57 \%$ & $41 \%$ \\
Buses & $64 \%$ & $70 \%$ & $63 \%$ \\
\hline
\end{tabular}

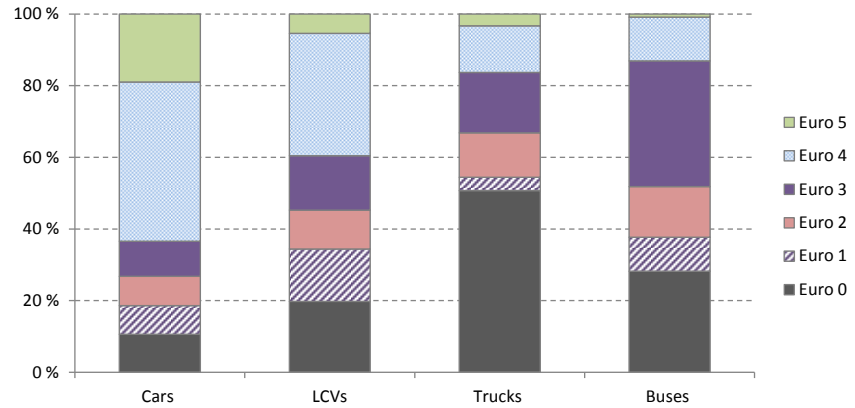

Figure 2. The distribution of diesel vehicles by emission standard. Source: Avtostat (2015c).

increased by 12 and $36 \%$, respectively (GKS, 2014a). Figure 2 shows the distribution of diesel vehicles by emission standard. Because gasoline vehicles emit practically no BC, gasoline vehicles were differentiated from diesel vehicles in the on-road fleet and not analyzed in this study.

\subsubsection{Superemitters}

The concept of superemitters is not well defined in the literature. The common approach, however, is to define superemitters as vehicles that have very high emissions compared to regular vehicles (sometimes referred to as "high-emitting vehicles"). In the vehicle testing studies, a cutoff level is used to determine the share of superemitters. For example, in Thailand, Subramanian et al. (2009) selected $4.7 \mathrm{~g} \mathrm{~kg}^{-1}$ as the cutoff for all diesel superemitters in their Bangkok study (Subramanian et al., 2009). In Chile, Faiz et al. (1996) used the cutoff level of $7.5 \mathrm{~g} \mathrm{~kg}^{-1}$ for buses in their Santiago study (Faiz et al., 1996). For national emission inventories, the cutoff approach cannot be used for emission calculations. The commonly accepted approach is to define the share of superemitters in the fleet and use specific emission factors for these high-emitting vehicles. As a result, this study uses assumptions about the share of superemitters in the diesel fleet to provide a more realistic emission inventory.

Superemitters should be represented in inventories because they are responsible for a large share of emissions. For example, Ban-Weiss et al. (2009) measured emissions from 226 diesel trucks driving through a highway tunnel in California and found that $10 \%$ of the highest-emitting trucks were responsible for about $40 \%$ of total BC from trucks. In Beijing, Wang et al. (2011) found that approximately $5 \%$ of the trucks are responsible for $50 \%$ of the BC emissions. In Slovenia, a study of 139 individual vehicles of different types showed that $25 \%$ of the highest-emitting diesel vehicles produce $63 \%$ of the BC emissions (Ježek et al., 2015). Preble et al. (2015) found that $20 \%$ of trucks emit $80 \%$ of the BC emissions from the Port of Oakland truck fleet (Preble et al., 2015).

Although superemitters emit a significant share of total emissions, there is a limited number of studies on their share of superemitters in the diesel fleet. For example, Subramanian et al. (2009) estimated that the fraction of superemitters in the studied diesel fleet in Bangkok is $15 \%$. In their study of BC and PM emissions from 251 trucks in California, Ban-Weiss et al. (2009) found that about $13 \%$ of the diesel fleet are superemitters. Bond et al. (2004) assumed with a high uncertainty that the share of superemitters for countries "similar" to the United States is 5\%. A recent study by the California Air Resources Board shows that $8 \%$ of trucks were classified as high emitters (emitting over $5 \%$ opacity) from a sample of over 1800 truck tests (CARB, 2015). We should note that the US EPA no longer uses the concept of superemitters to estimate vehicle emissions (EPA, 2015).

There are no known studies on superemitters in Russia. Bond et al. (2004) assumed that the share of superemitters in Eastern Europe and the former Soviet Union is $10 \%$. This estimate also was used in other studies (Yan et al., 2011, 2014). This study uses the assumption that the share of superemitters in the Russian diesel fleet is $15 \%$. We use a logistic function from Yan et al. (2011) to represent the rate at which normal vehicles become superemitters (Eq. 2):

$\operatorname{fr}(s)=$ gain $/ e^{(a \times(1-S / L)}$,

where fr is the fractional rate at which normal vehicles become superemitters (fraction per year), gain is the maximum rate of superemitter transition, $a$ determines the slope of the transition curve with age, $s$ is vehicle age, and $L$ is the age of vehicle life at which the rate becomes half the maximum.

Since retired (inactive) vehicles were already excluded from the registry, we modified the gain parameter in the formula to obtain the number of superemitters, which equal $15 \%$ of the total active diesel fleet. In this study, the parameters of the formula are as follows: $a=5.5 ; L=5.0$; and 
gain $=0.024$. The share of superemitters in the fleet depends on the vehicle age. Using Eq. (2) we calculated that this share is less than $3 \%$ for vehicles less than 5 years old, close to $18 \%$ among 10 -year-old vehicles, and $50 \%$ for 20 -year-old vehicles. Since the age distribution varies by vehicle type, using Eq. (1) we calculated the fraction of superemitters in the diesel fleet: $10 \%$ for cars, $17 \%$ for LCVs, $19 \%$ for trucks, and $15 \%$ for buses. As mentioned above, the overall share of superemitters in the diesel fleet is $15 \%$.

Using the information on diesel consumption by vehicle type and the percentage of superemitters in the fleet, we calculated that superemitters consumed $4000 \mathrm{t}$ of diesel, or $18 \%$ of total diesel consumption by on-road vehicles. Based on Yan et al. (2011) we assume that PM emission factors for diesel on-road superemitters is $8.31 \mathrm{~g} \mathrm{~kg}^{-1}$ for older-engine superemitters (Euro 0 and Euro 1) and $2.92 \mathrm{~g} \mathrm{~kg}^{-1}$ for newerengine superemitters (Euro 2-Euro 5). We also tested an assumption from McClintock (2011) that the emission factors of superemitters are 6 times higher than the average of the on-road diesel fleet. Using Russia-specific emission factors, we assume that the PM emission factor for superemitters is $0.39 \mathrm{~g} \mathrm{~km}^{-1}$ for cars, $0.59 \mathrm{~g} \mathrm{~km}^{-1}$ for LCVs, $0.8 \mathrm{~g} \mathrm{~km}^{-1}$ for trucks, and $1.31 \mathrm{~g} \mathrm{~km}^{-1}$ for buses. These two approaches yield very similar results (difference is about $3 \%$ ).

We assume that the share of superemitters in the off-road fleet is the same as in the on-road one (15\%). Following Bond et al. (2004), we assume that the PM emission factor for off-road superemitters is $12 \mathrm{~g} \mathrm{~kg}^{-1}$ and that the OC / BC ratio is 0.21 (Bond et al., 2004).

\subsubsection{Annual distance traveled}

The annual average distance traveled is one the most important parameters in the COPERT model. We use several sources to estimate the annual number of kilometers traveled by type of vehicles in Russia. NIIAT developed a methodology for assessing the residual value of vehicles based on their age and kilometers traveled (NIIAT, 1998). This methodology provides estimates of the annual average distance traveled by type of vehicles, country of production, and road type. In its emission calculation methodology, NIIAT (2006, 2012) estimated the average annual distance traveled for the total fleet. Avtostat conducted an extensive study of vehicle activity and estimated the average annual kilometers traveled by Russian and foreign-made cars. Avtostat also provided its estimates on average kilometers traveled by LCVs, trucks, and buses. We use the Avtostat assumptions for emission calculations. Table S4 shows the assumptions on average of annual kilometers traveled in different models/methodologies. Supplement Table S5 provides details on our assumptions on annual kilometers traveled by vehicles by Euro class.

The average speed is assumed to be $25 \mathrm{~km} \mathrm{~h}^{-1}$ in cities, $40 \mathrm{~km} \mathrm{~h}^{-1}$ on rural roads, and $90 \mathrm{~km} \mathrm{~h}^{-1}$ on highways. The assumption on the speed in cities is based on actual speed in Moscow and other large cities. The assumptions on the av- erage speed on rural roads and highways are based on maximum allowable (standard) speed on these types of roads in Russia. The share of vehicle-kilometers traveled (vkt) on urban roads is taken from the ICCT Roadmap model (ICCT, 2015). The share of vkt on urban roads is $75 \%$ for cars, LCVs, and buses and $50 \%$ for trucks. The rest of vkt is divided $40: 60$ between rural roads and highways.

\subsection{Emissions calculations}

$\mathrm{BC}$ emissions from diesel on-road vehicles were calculated using the COPERT 4 model with NIIAT emission factors. Superemitters were excluded from our initial emission calculations with the COPERT model. Instead, emissions from superemitters were calculated using Eq. (1) and added to COPERT results.

Table 4 shows the results of emission calculations from active diesel vehicles. Heavy-duty trucks emitted $60 \%$ of all on-road diesel $\mathrm{BC}$, while passenger cars emitted only $5 \%$. The results show that superemitters emitted $8.9 \mathrm{Gg}$ of $\mathrm{BC}$, or $43 \%$ of all diesel on-road BC emissions. The role of superemitters in emissions by type of vehicles varies from to about $40 \%$ for buses and heavy-duty trucks to $44 \%$ for cars and $48 \%$ for LCVs. The total BC emissions from on-road diesel vehicles are estimated at $20.7 \mathrm{Gg}$ in 2014 . We also estimated that normal vehicles have emitted $5.6 \mathrm{Gg}$ of OC emissions, and superemitters produced an additional $4.9 \mathrm{Gg}$ of OC in 2014 (see Supplement Table S6 for details).

As mentioned above, it is important to separate diesel vehicles from gasoline ones, exclude vehicles that are not in use, and factor in superemitters. If one assumed that all heavy-duty vehicles use diesel, $\mathrm{BC}$ emissions from trucks alone would be $39.7 \mathrm{Gg}$ of $\mathrm{BC}$, significantly overstating the total. Likewise, $\mathrm{BC}$ emissions from all registered diesel vehicles (as they appeared on the vehicle registry) are $29.1 \mathrm{Gg}$. Emissions from the adjusted fleet without accounting for superemitters would be $16.3 \mathrm{Gg}$ (see Supplement Tables S7-S9 for details).

\section{Off-road diesel sources}

\subsection{Rail}

The total length of railroads is $86000 \mathrm{~km}$, and about $60 \%$ of them are electrified (GKS, 2014b). Given the size of the country, the density of railroads is low compared to other European countries. Rail cargo turnover was 2301 billion metric ton kilometers (tkm) in 2014, which is almost 10 times larger than that of road transport (247 billion tkm). In 2013, diesel locomotives transported almost $15 \%$ of all rail cargo (GKS, 2014b).

The Russian Railways company (RZhD, based on the Russian acronym) is the largest owner of diesel locomotives in the country. RZhD owned 10400 electric locomotives and 10200 diesel locomotives in 2013, including 3500 line 
Table 4. BC emissions from active on-road diesel vehicles in 2014 (Gg).

\begin{tabular}{lrrrrr}
\hline & Cars & LCVs & Trucks & Buses & Total \\
\hline Euro 0 & 0.1 & 0.7 & 3.5 & 0.3 & 4.6 \\
Euro 1 & 0.0 & 0.3 & 0.3 & 0.1 & 0.8 \\
Euro 2 & 0.1 & 0.4 & 1.2 & 0.3 & 2.0 \\
Euro 3 & 0.1 & 0.5 & 1.6 & 0.4 & 2.7 \\
Euro 4 & 0.2 & 1.0 & 0.4 & 0.0 & 1.6 \\
Euro 5 & 0.0 & 0.0 & 0.1 & 0.0 & 0.1 \\
Total Euro 0-5 & 0.6 & 2.8 & 7.2 & 1.1 & 11.8 \\
Superemitters & 0.5 & 2.7 & 5.1 & 0.7 & 8.9 \\
\hline Total & 1.1 & 5.5 & 12.3 & 1.8 & 20.7 \\
\hline
\end{tabular}

haul and 6100 shunting locomotives (Balabin and Evpakov, 2013). In addition to RZhD's stock, large industrial companies also own about 12000 locomotives to form trains. In 2012, RZhD started using Euro 3 diesel (350 ppm) for its diesel locomotives (RZhD, 2013).

The locomotive fleet is old: about $50 \%$ of long-line-haul locomotives are more than 15 years old. Diesel locomotives in Russia have no emission controls. The EEA guidebook presents the emission factors for diesel locomotives based on average European fleet $\left(1.37 \mathrm{~g} \mathrm{~kg}^{-1}\right)$. Given that the Russian locomotives are older than those in Europe, we use the emission factor from Yan et al. (2014) for locomotives without emission controls. Thus, we assume that the PM emission factor for diesel locomotives in Russia is $4.62 \mathrm{~g} \mathrm{~kg}^{-1}$.

\subsection{Domestic navigation and fishing}

Domestic navigation and fishing represent different economic sectors but use similar combustion technologies. Liquid bulk ships, dry cargo carriers, and container ships mainly use heavy bunker fuel oil, while passenger ships, fishing boats, and tugs use diesel. Diesel ships tend to be smaller than those using bunker fuel oil. Almost all ships use diesel during maneuvering and while docked at shore. As a result, emissions from domestic navigation and fishing are presented in the same category.

Russia is a large marine state with the third-longest coastline in the world. There are 67 sea ports in Russia; although only a few are ice-free in winter. The largest areas of maritime activity are the Baltic Sea, the Black Sea region, and the Far East. The Arctic region accounts for 5.6\% of cargo turnover, but its maritime activity is rapidly expending given the increasingly ice-free Northern Sea Route. Most marine and fishing vessels in Russia are old. For example, over $70 \%$ of river and lake vessels are older than 25 years (Mintrans, 2015). Similarly, over $80 \%$ of fishing ships are over 20 years old (WCIOM, 2015). The cargo fleet has been shrinking: there were 3830 sea-going vessels in 2000, 3514 in 2005, and 2712 in 2014 . The number of river vessels decreased from 31800 in 2000 to 21800 in 2014 (GKS, 2015a).
Ships were estimated to have used $526 \mathrm{kt}$ of diesel in 2014. This does not include military consumption, which could be very significant. Ships were assumed to have no emission controls since Russia has no emission standards for them.

\subsection{Agriculture}

According to estimates from the Ministry of Agriculture, agricultural companies in 2014 owned 420000 agricultural tractors, 153000 harvesters, and 22000 other motor vehicles (Ministry of Agriculture, 2015). In Russia, the agricultural fleet has been shrinking (Ministry of Agriculture, 2015). For example, there were 15000 fewer tractors in 2014 than in 2013. In 2014, the retirement rate for tractors was $5.1 \%$, while the replacement rate was $3.2 \%$ (GKS, 2015b). Tractors produced in Russia, Belarus, and Ukraine constitute over $90 \%$ of the tractor fleet, and the majority of tractors are over 10 years old (Ministry of Agriculture, 2015). As a result, the availability of emission controls is very limited. Moreover, until recently, there were no emission standards for agricultural vehicles in Russia. Because of new emission standards for agricultural vehicles in Russia, emissions may possibly drop in the future. Since Russia has limited production of agricultural tractors (about $3 \%$ of new sales), foreign-made agricultural machinery dominates new sales (Agroinfo, 2015). The share of used tractors in the total imports was $20 \%$ in 2014. Tractors imported from Western countries were assumed to have emission controls; however, their share in the total agricultural fleet is very small (no more than $5 \%$ ). We assume that the distribution by emission standard is as follows: $95 \%$ are Stage 0 (without emission controls), and $5 \%$ meet Stage II standards.

\subsection{Industry}

\subsubsection{Mining}

The mining sector consumes about half of the industrial diesel. Russia is a major mineral and coal producer. Russia produced $357 \mathrm{Mt}$ of coal in 2014 and is also a leading global producer of many other mined commodities, including aluminum, copper, iron ore, lead, and nickel, among others (USGS, 2016).

Open-pit mining is widespread in Russia due to its relatively lower production costs. Sixty-five percent of the coal produced in 2014 was in open-pit mines (EMIS, 2014; GKS, 2015a). Mining trucks consume $70-80 \%$ of the diesel at open-pit mines due both to their large engines and the fact that mining operations continue nonstop. On average each truck operates well over $6300 \mathrm{~h} \mathrm{yr}^{-1}$ (Mining Magazine, 2007). The Belarusian company BELAZ supplies the majority of the largest mining trucks (Petrovich et al., 2013), and most BELAZ trucks are equipped with Cummins and MTU engines. The average life of mining trucks is short: BELAZ 
trucks operate for 5-7 years (Zvonar, 2010), while Caterpillar mining trucks operate for 9-12 years (Anistratov, 2013).

Russia has no emission standards for off-road mining vehicles, and, as a result, Western companies can supply engines without emission controls. For example, about $88 \%$ of Cummins engines in Russia have no controls, and the remaining $12 \%$ meet US EPA Tier 1 requirements (R. Mueller, personal communication, 2014). A small population of Caterpillar and Komatsu trucks also meet Tier 1 or Tier 2 requirements.

The role of the mining industry in diesel consumption and $\mathrm{BC}$ emissions is especially important in the Russian Arctic. For example, in their study of BC emissions in the Arctic, Evans et al. (2015) found that the mining industry emits about $70 \%$ of all diesel BC emission in the Murmansk region. A second study on $\mathrm{BC}$ emissions in the Russian Arctic found that the mining industry emits $80 \%$ of BC emissions from combustion in Russia's Arctic zone (Morozova, 2015). We assume that $88 \%$ of engines in the mining industry are Tier 0 (1991 - Stage I) and 12\% are Tier 1 (Stage I).

\subsubsection{Construction}

The construction industry is an important sector of the Russian economy. In 2013, 5.7 million people were employed in construction ( $8 \%$ of the labor force). Over 226000 construction companies worked in Russia in 2014 (GKS, 2015a), indicating that most of them are small businesses. The construction industry uses more varieties of diesel engines than any other sector of the economy. Most of construction equipment is old and lacks emission controls. About 30-50\% of these excavators, loaders, bulldozers, and graders have reached their end of useful life (Rosstat, 2014). Though up to $60 \%$ of construction machinery is imported depending on type of vehicles, they do not necessarily have emission controls. We assume that the distribution by emission standard is as follows: $90 \%$ of construction machinery is Stage 0 (without emission controls), and $10 \%$ has some emission controls.

\subsubsection{Other industry}

Other types of industries that use diesel include production of iron, steel, non-ferrous metals, chemicals, machinery, food, paper, wood products, textiles, and other types of goods. In these industries, a huge variety of diesel machinery and equipment exists and is assumed to be primarily heavy industrial equipment with no emission controls.

\subsection{Diesel generators}

About $60 \%$ of Russia's territory is not connected to the centralized electricity grid (Suslov, 2012). Twenty million people live in these off-grid areas, which include cities, towns, and villages (Zatopliaev and Redko, 2004). Stationary diesel generators produce electricity in small isolated grids in remote locations. About 47000 diesel generators provide electricity; 12000 of these are in the northern part of the country.
The typical generator power capacity ranges from $100 \mathrm{~kW}$ to $3.5 \mathrm{MW}$. At the beginning of the $2000 \mathrm{~s}$, the installed capacity of diesel generators was about 17 million $\mathrm{kW}$, or $8 \%$ of the total installed capacity in Russia (Minenergo, 2012). According to the Russian statistical service, large diesel power stations generated $4500 \mathrm{GWh}$ of electricity in 2014 (Fedstat, 2015a). In addition to electricity generation, diesel can be used to produce heat. Diesel boilers and heat pumps are used in areas without centralized district heating. The process of external combustion in boilers is quite different from that in diesel engines, and as a result PM emission factors and $\mathrm{BC} / \mathrm{PM}$ ratios for external combustion are lower than those from internal combustion engines (Bond et al., 2004). In 2014 diesel generators used $1.034 \mathrm{Mt}$ of diesel, and heat plants used an additional $315 \mathrm{kt}$.

\section{Results of BC emission calculations}

Table 5 presents the results of emission calculations from offroad diesel sources in Russia as well as the total for on-road transportation in 2014. We estimate that all off-road sources emitted $28.5 \mathrm{Gg}$ of BC and $6.7 \mathrm{Gg}$ of OC. The largest emission contributors in the off-road sector are industry, locomotives, and agricultural machinery. This study also includes superemitters in the off-road diesel fleet. The role of superemitters in the off-road fleet is less important than for the on-road fleet due to differences in emission factors between normal engines and superemitters. We estimate that off-road superemitters are responsible for $23 \%$ of BC emissions from off-road sources.

Rail is the largest source of off-road BC emissions because of outdated equipment and large emission factors, as well as the extensive use of diesel locomotives in off-grid parts of Russia. Industry is a large source because of the diversity of small uses without emission controls. Diesel generators without emission controls produced more BC emissions than the mining industry because of the lack of emission controls and larger emission factors.

These results show that off-road diesel sources emit $58 \%$ of the total diesel BC in Russia. These high levels of emissions from off-road sources are a result of the limited use of emission control technologies, a function both of the equipment age and the lack of regulations for new equipment. This contrasts with emissions from on-road vehicles, where standards were introduced a decade ago, and emissions have subsequently dropped. While consuming $73 \%$ of the diesel fuel in the country, on-road vehicles produced $42 \%$ of BC emissions in 2014.

\section{Comparison with other studies}

There have been several studies looking at BC emissions in Russia across a range of sectors, but the majority of these studies use fuel-based mass balance approaches to calculat- 
Table 5. BC and OC emissions in Russia in 2014 (Gg).

\begin{tabular}{lrr}
\hline Sector & BC & OC \\
\hline On-road vehicles & 20.7 & 10.5 \\
Rail & 8.4 & 1.7 \\
Other industry & 5.3 & 1.1 \\
Mining & 4.4 & 1.3 \\
Agriculture & 4.2 & 1.2 \\
Diesel generators & 4.1 & 0.8 \\
Construction & 1.2 & 0.4 \\
Ships & 0.5 & 0.1 \\
Other sectors & 0.4 & 0.1 \\
Total & 49.2 & 17.2 \\
\hline
\end{tabular}

ing emissions. In previous studies, emissions from on-road transport were estimated based on the number of registered vehicles or in the best case on vehicles separated into a few emission standards. A limited number of studies have assessed the existence of control technologies and other detailed real-world activity data. None of the studies accounted for superemitters in the fleet. Table 6 below shows the result of several previous studies covering total anthropogenic BC emissions, emissions from transport, or all diesel sources.

There are two wide categories of studies on Russian BC emissions. Emission estimates in the first category are based on fuel consumption, use global or regional emission factors, and mostly do not use Russian activity data. For example, Bond et al. (2004) combined fuel consumption data and application of combustion technologies and emission controls (Bond et al., 2004; Sarofim et al., 2009). Lamarque et al. (2010), updating the Bond data (2004), estimated that diesel engines are likely to be the fourth-largest source of BC emissions in Russia after residential/domestic sources, forest fires, and industry (EPA, 2012; Lamarque et al., 2010). The International Institute for Applied Systems Analysis (IIASA) uses the Regional Air Pollution INformation and Simulation (RAINS) model and the Evaluating the Climate and Air Quality Impacts of Short-Lived Pollutants (ECLIPSE) model to estimate $\mathrm{PM}$ and $\mathrm{BC}$ emissions. $\mathrm{BC}$ emissions from transport were estimated to be $52 \mathrm{Gg}$ in 2010 (Sand et al., 2016).

The second category of Russian BC studies is based on Russian activity data, where Russia-specific emission factors were used for on-road transport and/or bottom-up fuel consumption data. Some of these studies were completed in the framework of BC mitigation efforts in the Arctic. In 2015, Russia submitted its first report to the Arctic Council on $\mathrm{BC}$ and methane emission reductions. The total Russiawide $\mathrm{BC}$ emissions were estimated to be $358.5 \mathrm{Gg}$ in 2013 (MNRE, 2015). Transport was not determined to be a significant source of $\mathrm{BC}$ emissions ( $7.7 \mathrm{Gg}$, or just $2 \%$ of the emissions). An international group of scientists led by the US Department of Energy estimated BC emissions in the Russian Arctic and in Russia from anthropogenic sources (Huang et al., 2015). Drawing on local Russian information, Russian
BC emissions were estimated to be $224 \mathrm{Gg}$ in 2010 . Using vehicle registry data, $\mathrm{BC}$ emissions from transport were estimated to be $45.3 \mathrm{Gg}$ (Huang et al., 2015). The authors assumed that all registered vehicles are actively used and all vehicles use diesel fuel. The paper does not present the vehicular emissions by vehicle type or emission standard.

NIIAT estimated that Russian on-road vehicles emitted 53.9 Gg PM in 2006 (Donchenko, 2007) and 38.5 Gg PM in 2011 (Donchenko, 2013). NIIAT used the Russian PM emission factors and, until recently, had not calculated BC emissions. NIIAT used detailed information about the number of diesel vehicles and adjusted the registry to reflect the share of the active fleet. NIIAT does not account for superemitters in emission calculations.

Evans et al. (2015) used the IEA diesel data and estimated BC emissions from all diesel sources, including diesel transport, in Russia. Using fuel-based emission factors from the EEA emission guidebook and NIIAT emission factors, $\mathrm{BC}$ emissions from on-road transport were estimated to be about 20.0 Gg (Evans et al., 2015). Similarly, Kholod and Evans (2016) use the Global Change Assessment Model (GCAM) to build a forecast for BC emissions from on-road transport in Russia. Total BC emissions from on-road transport were estimated to be about $20.0 \mathrm{Gg}$ in 2015 . The model, however, does not calculate emissions from vehicles by emission standard, which is important for developing emission reduction strategies.

We can conclude that the results of the emission calculations presented in the current study are close to those studies that used detailed Russian activity data (number of active diesel vehicles, annual average distance traveled, and Russian emission factors). The advantages of the current study are that we present the $\mathrm{BC}$ emissions from on-road transport by vehicle types and emission standards, factor in superemitters, and also present OC emissions from on-road vehicles and off-road diesel sources.

\section{Uncertainty}

There are two major sources of uncertainty in BC emission inventories: (1) emission factors and (2) activity data. Emission factor uncertainty includes uncertainties in $\mathrm{PM}$ emission factors for normal vehicles and superemitters and BC / PM speciation ratios. NIIAT does not report the uncertainty in PM emission factors for on-road vehicles. In COPERT, the uncertainty for PM emission factors is estimated to be 20 $30 \%$ (Kouridis et al., 2010). Uncertainty in PM emission factors for off-road sources is 30-60\% for agricultural vehicles, $25-50 \%$ for ships, and an order of magnitude for industry (EEA, 2013).

Activity data also present uncertainties because of uncertainties in underlying surveys or estimation methodologies. This includes data on fuel consumption by sector, distribution by vehicle type, annual number of kilometers traveled, 
Table 6. The results of BC emission studies for Russia.

\begin{tabular}{|c|c|c|c|}
\hline Study & Base year & Emission source categories & $\mathrm{BC}$ emissions $(\mathrm{Gg})$ \\
\hline Bond et al. (2004) & 1996 & $\begin{array}{l}\text { Agricultural burning, industry, open fire, power generation, } \\
\text { residential biofuels, road transport, off-road transport }\end{array}$ & 200 \\
\hline \multirow[t]{2}{*}{ Lamarque et al. (2010) } & \multirow[t]{2}{*}{2000} & $\begin{array}{l}\text { Residential/domestic sources, forest fires, industry, diesel } \\
\text { engines }\end{array}$ & 360 \\
\hline & & Diesel transport (including aircrafts and marine shipping) & 32 \\
\hline \multirow{3}{*}{$\begin{array}{l}\text { IIASA } \\
\text { ECLIPSE dataset } \\
\text { (Sand et al., 2016) }\end{array}$} & \multirow[t]{3}{*}{2010} & All anthropogenic emissions (domestic, energy/industrial/ & 182 \\
\hline & & waste, transport, agricultural fires, gas flaring) & \\
\hline & & Transport & 52 \\
\hline \multirow[t]{2}{*}{ Huang et al. (2015) } & \multirow[t]{2}{*}{2010} & Flaring, residential, transport, industry, power plants & 224 \\
\hline & & On-road transport & 45 \\
\hline $\begin{array}{l}\text { Russia's National } \\
\text { Report to the Arctic }\end{array}$ & \multirow[t]{2}{*}{2013} & $\begin{array}{l}\text { All anthropogenic emissions (agriculture, industry, transport, } \\
\text { services) }\end{array}$ & 359 \\
\hline Council (MNRE, 2015) & & Transport & $8 \mathrm{Gg}$ \\
\hline Donchenko (2007) & 2006 & On-road transport & $\begin{array}{r}54 \mathrm{Gg} \mathrm{PM} \\
(29 \mathrm{Gg} \mathrm{BC})^{*}\end{array}$ \\
\hline Donchenko (2013) & 2011 & On-road transport & $\begin{array}{r}39 \mathrm{Gg} \mathrm{PM} \\
(20 \mathrm{Gg} \mathrm{BC})^{*}\end{array}$ \\
\hline \multirow[t]{2}{*}{ Evans et al. (2015) } & \multirow[t]{2}{*}{2010} & All diesel sources & 46 \\
\hline & & On-road diesel transport & 20 \\
\hline \multirow[t]{2}{*}{ This study } & \multirow[t]{2}{*}{2014} & All diesel sources & 49 \\
\hline & & On-road diesel transport & 21 \\
\hline
\end{tabular}

* Assuming that BC / PM speciation ratio for on-road transport is 0.53 (EEA, 2013).

and assumptions about emission controls. Fuel data differ by a lot, as does the average annual distance traveled. The distribution by vehicle type and controls for on-road transport is less uncertain. Off-road uncertainty on emission controls is larger because more emission controls may exist than was assumed. We use several approaches to minimize uncertainties in the activity data, including multiple approaches to data collection, cross-checks with the literature, and expert judgments.

Uncertainty in $\mathrm{BC} / \mathrm{PM}_{2.5}$ speciation ratios for on-road vehicles is $5-10 \%$ for light-duty vehicles and $20 \%$ for heavy-duty engines. The speciation ratio uncertainty for offroad diesel sources is $20 \%$ (EEA, 2013). The speciation ratios are not a major source of uncertainty in emission inventories for diesel BC sources.

Our data on fuel consumption are based on bottom-up calculations and are close to the Russian official statistics. While there is uncertainty in the distribution between economic sectors, the total domestic diesel supply is well determined.

Assumptions on emission controls do not significantly contribute to uncertainties in emissions because about 90 $95 \%$ of off-road diesel engines are assumed to have no emission controls. However, real emission factors for Russian diesel sources are not well understood. For on-road vehicles, the distribution by emission standards is well determined based on the registry. The key uncertainty here is the assumption of the share of active vehicles.

Another source of uncertainty is the share of superemitters in the on-road and off-road fleets. For emission calculations, the share of superemitters is assumed to be $15 \%$. This number is to some extent arbitrary because it was determined based on a small number of studies. In addition, heavy-duty trucks are designed to meet emission limits up to a specified maximum loading, and overloading can significantly increase the share of high-emitting vehicles (World Bank, 2014). There is evidence that Russian drivers tend to overload their trucks, especially on the long-haul routes, to save time and increase their short-term profit. According to the Russian Federal Road Agency, 30-40\% of heavy-duty trucks are overloaded on average by $45 \%$ (Avtodor, 2015). As a result, the share of superemitters in the truck fleet might be higher. For on-road vehicles, three major sources of uncertainty were considered: the share of superemitters in the fleet, average annual distance traveled, and emissions factors for normal vehicles and superemitters. Supplement Table S10 shows the assumptions for uncertainty calculations for onroad vehicles. 
The central value of $\mathrm{BC}$ emissions from on-road vehicles in 2014 is $20.7 \mathrm{Gg}$ with an uncertainty range of -10.2 to $+7.3 \mathrm{Gg}$. The central value of $\mathrm{OC}$ emissions is $10.5 \mathrm{Gg}$ with an uncertainty range of -4.2 to $+3.2 \mathrm{Gg}$.

The uncertainty in BC emissions from off-road sources is estimated in the range from 19.2 to $42.1 \mathrm{Gg}$ (or $-33 /+48 \%$ ) with the central value of $28.5 \mathrm{Gg}$. OC emissions from offroad engines are in the range from 4.5 to $9.8 \mathrm{Gg}$ with the central value of $6.7 \mathrm{Gg}$. The total emissions from diesel sources in Russia are estimated to be $49.2 \mathrm{Gg}$ of $\mathrm{BC}$ and $17.2 \mathrm{Gg}$ of OC in 2014.

\section{Conclusions}

In this paper, we estimate $\mathrm{BC}$ and $\mathrm{OC}$ emissions from diesel sources in Russia. We use detailed vehicle registry data containing information from about 49 million records to analyze on-road transport in Russia. We distinguish diesel vehicles from gasoline ones, estimate the share of active vehicles in the fleet, use detailed information on distribution by vehicles types and emission standards, and use Russia-specific emission factors for emission calculations. This study also factors in the role of superemitters in BC emissions. Emissions from on-road diesel vehicles are estimated at $20.7 \mathrm{Gg}$ of BC and $10.5 \mathrm{Gg}$ of $\mathrm{OC}$ in 2014 . Heavy-duty trucks emitted $60 \%$ of BC, while diesel passenger cars emitted only $5 \%$ due to their small share in the total passenger fleet and availability of emission controls. Assuming that the share of superemitters is $15 \%$ in the on-road diesel fleet, we estimate that these high-emitting vehicles are responsible for $33 \%$ of all $\mathrm{BC}$ emissions from on-road vehicles. Under this assumption, the role of superemitters in emissions by vehicle type varies from about $40 \%$ for trucks and buses to $40 \%$ for cars and $48 \%$ for LCVs.

We also estimate BC emissions from off-road diesel sources - including diesel locomotives; ships; and off-road engines in industry, construction, and agriculture - and from diesel generators. We estimate that off-road diesel sources emitted $28.5 \mathrm{Gg}$ of BC and $6.7 \mathrm{Gg}$ of OC in Russia in 2014. Stationary engines in industry are the largest source of offroad BC emissions, followed by locomotives, agriculture, and diesel generators. Off-road diesel sources emitted $58 \%$ of all diesel BC emissions. Off-road superemitters emitted $23 \%$ of emissions from off-road diesel sources. These results do not include emissions from military diesel usage. Military vehicles can be a large source of $\mathrm{BC}$ emissions given that they use high-sulfur diesel.

The total emissions from diesel sources in Russia are estimated to be $49.2 \mathrm{Gg}$ of BC and $17.2 \mathrm{Gg}$ of OC in 2014.

\section{Data availability}

All the cited data are available at their cited source and could be provided by the corresponding author, Nazar Kholod (nazar.kholod@pnnl.gov). Russia's on-road vehicle registry can be bought from the Russian company Avtostat (http: //avtostat-info.com/Home/Contact).

\section{The Supplement related to this article is available online at doi:10.5194/acp-16-11267-2016-supplement.}

Disclaimer. The views and opinions expressed in this paper are those of the authors alone.

Acknowledgements. The authors are grateful for research support provided by the US Environmental Protection Agency, Office of International and Tribal Affairs (under the inter-agency agreement DW-089924383), and the US Department of State. Battelle Memorial Institute operates the Pacific Northwest National Laboratory for the US Department of Energy under contract DE-AC05-76RL01831. We thank the members of the Technical Steering Group for their helpful comments and suggestions.

Edited by: S. A. Nizkorodov

Reviewed by: two anonymous referees

\section{References}

Agroinfo: Russian market of agricultural machinery in 2014, Agroinfo, available at: http://agroinfo.com/ rossijskij-rynok-selxoztexniki-v-2014-godu-1603201505/ (last access: 26 February 2016), 2015 (in Russian).

Anistratov, K.: Justification of mining fleet selection for trucks with payload capacity of 40-100 tons, Mining Business, 1, 1-10, 2013 (in Russian).

Avtodor: On roads without overloading, Russian Federal Road Agency, Moscow, available at: http://rosavtodor.ru/activity/123/ 15335.html (last access: 5 May 2016), 2015.

Avtostat: Vehicle fleet in Russia in 2014, Avtostat, available at: http: //avtostat-info.com/Article/130 (last access: 18 February 2016), 2015a (in Russian).

Avtostat: Fuel consumption by on-road transport in Russia in 2014, available at: http://www.autostat.ru/news/view/20962/, last access: 28 October 2015 b.

Avtostat: Park of PC, LCV, HCV, BUS as of 01.01.2015 (Russia, Russian regions), Dataset, Avtostat, Togliatti, Russia, 2015c.

Avtostat: Vehicle fleet in Russia in 2015, Avtostat, available at: http://avtostat-info.com/Article/189, last access: 21 May 2016 (in Russian).

Balabin, V. N. and Evpakov, V. V.: Production of switch and industrial diesel locomotives: Developmental problems of the industry, Transport of the Russian Fedeartion, 6, 30-33, 2013 (in Russian).

Ban-Weiss, G. A., Lunden, M. M., Kirchstetter, T. W., and Harley, R. A.: Measurement of black carbon and particle number emission factors from individual heavy duty trucks, Environ. Sci. Technol., 43, 1419-1424, 2009. 
Bond, T. and Sun, H.: Can reducing black carbon emissions counteract global warming?, Environ. Sci. Technol., 39, 5921-5926, 2005.

Bond, T., Streets, D., Yarber, K., Nelson, S., Woo, J.-H., and Klimont, Z.: A technology-based global inventory of black and organic carbon emissions from combustion, J. Geophys. Res., 109, D14203, doi:10.1029/2003jd003697, 2004.

Bond, T. C., Doherty, S. J., Fahey, D. W., Forster, P. M., Berntsen, T., DeAngelo, B. J., Flanner, M. G., Ghan, S., Kärcher, B., Koch, D., Kinne, S., Kondo, Y., Quinn, P. K., Sarofim, M. C., Schultz, M. G., Schulz, M., Venkataraman, C., Zhang, H., Zhang, S., Bellouin, N., Guttikunda, S. K., Hopke, P. K., Jacobson, M. Z., Kaiser, J. W., Klimont, Z., Lohmann, U., Schwarz, J. P., Shindell, D., Storelvmo, T., Warren, S. G., and Zender, C. S.: Bounding the role of black carbon in the climate system: A scientific assessment, J. Geophys. Res., 118, 5380-5552, doi:10.1002/jgrd.50171, 2013.

CARB: Evaluation of particulate matter filters in on-road heavyduty diesel vehicle applications, California Air Resources Board, available at: http://www.arb.ca.gov/msprog/onrdiesel/ documents/DPFEval.pdf (last access: 10 May 2016), 2015.

Donchenko, V.: Environmental performances of motor vehicles and fuels in the Russian Federation and CIS countries Scientific Research Institute of Automobiles and Transportation (NIIAT), Moscow, available at: http://www.unep.org/transport/pcfv/PDF/ Session4-TbilisiRegionalWorkshop-VadimDonchenko.pdf (last access: 21 May 2016), 2007.

Donchenko, V.: Environmental performances of motor vehicles and fuels in the Russian Federation, Scientific Research Institute of Automobiles and Transportation (NIIAT), Moscow, Russia, 2013.

Donchenko, V., Trofimenko Y., Kunin Y., Ruzski A., Baryshev L., Mekhonoshin V., and Sazonova G.: Assessment of pollutants and greenhouse gases emissions from motor vehicles in Moscow using a transport model, Presented at the "City Transportation and Environment of a Modern City" conference, 6 April 2016, Moscow, Russia, 2016.

EEA: EMEP/EEA air pollutant emission inventory guidebook - 2013, European Environment Agency, Copenhagen, Denmark, available at: http://www.eea.europa.eu/publications/ emep-eea-guidebook-2013 (last access: 15 July 2014), 2013.

EMIS: Coal mining sector. Russia, Emerging Markets Information Service, available at: https://www.emis.com/sites/default/files/ RussiaCoalMiningSectorReport.pdf (last access: 15 May 2016), 2014.

Emisia: COPERT (COmputer Programme to Calculate Emissions from Road Transport), prepared for the European Environment Agency, available at: http://www.emisia.com/copert/, last access: 15 July 2015.

EPA: Report to Congress on black carbon, US Environmental Protection Agency, EPA-450/R-12-001, Washington DC, USA, available at: http://www.epa.gov/blackcarbon/ (last access: 15 July 2014), 2012.

EPA: Exhaust emission rates for heavy-duty on-road vehicles in MOVES 2014. EPA-420-R-15-015a, US Environmental Protection Agency, Ann Arbor, MI, USA, available at: http://www.epa. gov/otaq/models/moves/moves-reports.htm (last access: 13 May 2016), 2015.
EPA: Reduction of black carbon from diesel sources in the Russian Arctic, US Environmental Protection Agency, availbale at: https://www.epa.gov/international-cooperation/ black-carbon-diesel-initiative-russian-arctic, last access: 26 May 2016.

Eurasian Commission: On requirements for automobile and aviation gasoline, diesel and marine fuel, jet fuel and heating oil, Technical Regulation TR CU 013/2011 dated 18 October 2011, Eurasian Commission, Moscow, available at: http://www.eurasiancommission.org/ru/act/texnreg/deptexreg/tr/ Pages/trebBenzin.aspx (last access: 13 April 2014), 2011a (in Russian).

Eurasian Commission: On safety of motor vehicles, Technical Regulation TR CU 010/2011 dated 18 October 2011, Eurasian Commission, Moscow, available at: http://www.eurasiancommission. org/ru/act/texnreg/deptexreg/tr/Documents/P_823_1.pdf (last access: 26 October 2015), 2011b (in Russian).

Eurasian Commission: On Safety of Agricultural and Forestry Tractors and Trailers, Technical Regulation TR CU 031/2012 dated 20 July 2012, Eurasian Commission, Moscow, available at: http://www.eurasiancommission.org/ru/act/texnreg/deptexreg/tr/ Documents/P_60.pdf (last access: 26 October 2015), 2012 (in Russian),

Evans, M., Kholod, N., Malyshev, V., Tretyakova, S., Gusev, E., Yu, S., and Barinov, A.: Black carbon emissions from Russian diesel sources: case study of Murmansk, Atmos. Chem. Phys., 15, 8349-8359, doi:10.5194/acp-15-8349-2015, 2015.

Faiz, A., Weaver, C. S., and Walsh, M. P.: Air pollution from motor vehicles: standards and technologies for controlling emissions, World Bank, Washington, DC, USA, 1996.

Fedstat: Electricity produced by diesel generators, 2010-2015, Unified Interdepartmental Statistical Information System, available at: http://fedstat.ru/indicator/data.do?id=40557, last access: 19 October 2015a (in Russian).

Fedstat: Average number of employees in small enterprises, Unified Interdepartmental Statistical Information System, available at: http://fedstat.ru/indicator/data.do?id=33434, last access: 19 October 2015b (in Russian).

Fedstat: Production of main goods in the Russian Federation, Unified Interdepartmental Statistical Information System, available at: http://fedstat.ru/indicator/data.do?id=40557, last access: 19 October 2015c (in Russian).

Fedstat: Average number of employees in micro enterprises, Unified Interdepartmental Statistical Information System, available at: http://fedstat.ru/indicator/data.do?id=40651, last access: 19 October 2015d (in Russian).

Fedstat: Fuels Used as a Motor Fuel, Unified Interdepartmental Statistical Information System, available at: http://fedstat.ru/ indicator/data.do?id=40478, last access: 19 October $2015 \mathrm{e}$.

Fedstat: Number of micro enterprises, Unified Interdepartmental Statistical Information System, available at: http://fedstat.ru/ indicator/data.do?id=40652, last access: 19 October $2015 \mathrm{f}$ (in Russian).

Fedstat: Number of small enterprises, Unified Interdepartmental Statistical Information System, available at: http://fedstat.ru/ indicator/data.do?id=33474, last access: 19 October $2015 \mathrm{~g}$ (in Russian)

Fedstat: Diesel fuel used by vehicles owned by enterprises, Unified Interdepartmental Statistical Information System, available at: 
http://fedstat.ru/indicator/data.do?id=37264, last access: 19 October 2015h (in Russian).

GBD: The global burden of disease study 2013, Institute for Health Metrics and Evaluation, Seattle, WA, available at: http://ghdx. healthdata.org/gbd-data-tool, last access: 12 July 2016.

GKS: Russian Statistical Yearbook 2014, Federal Statistics Service of the Russian Federation, Moscow, available at: http://www.gks.ru/wps/wcm/connect/rosstat_main/rosstat/ru/ statistics/publications/catalog/doc_1135087342078 (last access: 13 October 2015), 2014a.

GKS: Transport and Communication in Russia. 2014 Statistical Yearbook. Federal Statistics Service of the Russian Federation, available at: http://www.gks.ru/bgd/regl/B14_5563/ IssWWW.exe/Stg/02-02.doc (last access: 19 October 2015), 2014b.

GKS: Russian Statistical Yearbook 2015. Federal Statistics Service of the Russian Federation, available at: http://www.gks.ru/free doc/doc_2015/year/year15.rar (last access: 26 February 2016), 2015a.

GKS: Availability of machines and their power capacity in agricultural companies in the Russian Federation in 2014, Federal Statistics Service of the Russian Federation, Moscow, available at: http://www.gks.ru/wps/wcm/connect/rosstat_main/rosstat/ru/ statistics/publications/catalog/doc_1265196018516 (last access: 26 February 2016), 2015 b.

Government of Russian Federation: Decisions of the meeting from 15 October 2015 on refinery modernizations, available at: http: //government.ru/orders/20105/, last access: 18 November 2015.

Hansen, J. and Nazarenko, L.: Soot climate forcing via snow and ice albedos, P. Natl. Acad. Sci., 101, 423-428, 2003.

Huang, K., Fu, J. S., Prikhodko, V. Y., Storey, J. M., Romanov, A., Hodson, E. L., Cresko, J., Morozova, I., Ignatieva, Y., and Cabaniss, J.: Russian anthropogenic black carbon: Emission reconstruction and Arctic black carbon simulation, J. Geophys Res., 120, 11306-11333, doi:10.1002/2015JD023358, 2015.

ICCT: Global Transportation Roadmap Model International Council on Clean Transportation, available at: http://www.theicct.org/ global-transportation-roadmap-model, last access: 15 September 2015.

IEA: Key world energy statistics, International Energy Agency, Paris, France, 2015a.

IEA: Energy balances of non-OECD countries, International Energy Agency, Paris, France, 2015b.

Ježek, I., Katrašnik, T., Westerdahl, D., and Močnik, G.: Black carbon, particle number concentration and nitrogen oxide emission factors of random in-use vehicles measured with the onroad chasing method, Atmos. Chem. Phys., 15, 11011-11026, doi:10.5194/acp-15-11011-2015, 2015.

Kholod, N. and Evans, M.: Reducing black carbon emissions from diesel vehicles in Russia: An assessment and policy recommendations, Environ. Sci. Policy, 56, 1-8, doi:10.1016/j.envsci.2015.10.017, 2016.

Koch, D. and Del Genio, A. D.: Black carbon semi-direct effects on cloud cover: review and synthesis, Atmos. Chem. Phys., 10, 7685-7696, doi:10.5194/acp-10-7685-2010, 2010.

Kouridis, C., Gkatzoflias, D., Kioutsioukis, I., Ntziachristos, L., Pastorello, C., and Dilara, P.: Uncertainty estimates and guidance for road transport emission calculations. Report EUR 24296 EN-
2010, Institute for Environment and Sustainability, Luxembourg, 2010.

Lamarque, J.-F., Bond, T. C., Eyring, V., Granier, C., Heil, A., Klimont, Z., Lee, D., Liousse, C., Mieville, A., Owen, B., Schultz, M. G., Shindell, D., Smith, S. J., Stehfest, E., Van Aardenne, J., Cooper, O. R., Kainuma, M., Mahowald, N., McConnell, J. R., Naik, V., Riahi, K., and van Vuuren, D. P.: Historical (1850-2000) gridded anthropogenic and biomass burning emissions of reactive gases and aerosols: methodology and application, Atmos. Chem. Phys., 10, 7017-7039, doi:10.5194/acp10-7017-2010, 2010.

McClintock, P.: Enhanced remote sensing performance based pilot program, Environmental Systems Products Inc, Tiburon, CA, USA, 2011.

Minenergo: Performance and development of the energy system in Russia in 2011, Ministry of Energy of the Russian Federation, Moscow, available at: http://www.minenergo.gov.ru/ system/download-pdf/3399/3196 (last access: 21 May 2016), 2012 (in Russian).

Minenergo: Production and domestic supply of oil products in 2014, Ministry of Energy of the Russian Federation, Moscow, available at: http://minenergo.gov.ru/node/92, last access: 18 November 2015 (in Russian).

Mining Magazine: BELAZ at Apatity, Mining Magazine, UK, 47, October, 2007.

Ministry of Agriculture: National Report 2014. Ministry of Agriculture of the Russian Federation. Moscow, available at: http:// mcx.ru/documents/file_document/v7_show/32460..htm, last access: 13 October 2015 (in Russian).

Mintrans: Transport of the Russian Federation in 2014, Ministry of Transport of the Russian Federation, Moscow, available at: http: //www.mintrans.ru/upload/iblock/5cd/stat_2014.pdf (last access: 21 May 2016), 2015 (in Russian).

MNRE: National report on the actions for black carbon and methane emissions reductions, Ministry of Natural Resources and Environment of the Russian Federation, Moscow, available at: https://oaarchive.arctic-council.org/bitstream/handle/11374/ 1168/EDOCS-\%232709-v1-Russia_2015_Black_Carbon_ Methane_National_Report.PDF?sequence $=4 \&$ is Allowed $=\mathrm{y}$, last access: 30 July 2015.

Morozova, I.: Recent Russian BC emissions inventory: Case of the Russian Arctic. Presenation at the TFEIP/US DOE workshop "Improving black carbon emission estimates \& abatement”, Milan, Italy, 14 May 2015, available at: http://www. tfeip-secretariat.org/2015-meeting-milan/, last access: $15 \mathrm{Au}-$ gust 2015.

NIIAT: The assessment methodology for estimating the residual value of vehicles with regard to technical condition, Scientific Research Institute of Automobiles and Transportation, Moscow, Russia, 1998.

NIIAT: Calculation instruction (methodology) for inventory of emissions from vehicles into the air, Scientific Research Institute of Automobiles and Transportation, Moscow, Russia, 2006 (in Russian).

NIIAT: Calculation instruction (methodology) for emissions inventory from vehicles on the territory of the largest cities (based on Moscow example), Scientific Research Institute of Automobiles and Transportation, Moscow, Russia, 2012 (in Russian). 
Ntziachristos, L., Gkatzoflias, D., Kouridis, C., and Samaras, Z.: COPERT: A European road transport emission inventory model, Information Technologies in Environmental Engineering, 491504, doi:10.1007/978-3-540-88351-7_37, 2009.

Petrovich, A. A., Belyavskiy, D. A., and Garavskiy, A. O.: BELAZ trucks at open pit mines in Russia, Mining J., 1, 75-77, 2013 (in Russian).

Pope III, C. A., Burnett, R. T., Turner, M. C., Cohen, A., Krewski, D., Jerrett, M., Gapstur, S. M., and Thun, M. J.: Lung cancer and cardiovascular disease mortality associated with ambient air pollution and cigarette smoke: shape of the exposure-response relationships, Environ. Health Persp., 119, 1616-1621, 2011.

Preble, C. V., Dallmann, T. R., Kreisberg, N. M., Hering, S. V., Harley, R. A., and Kirchstetter, T. W.: Effects of particle filters and selective catalytic reduction on heavy-duty diesel drayage truck emissions at the Port of Oakland, Environ. Sci. Technol., 49, 8864-8871, 2015.

Quinn, P. K., Bates, T. S., Baum, E., Doubleday, N., Fiore, A. M., Flanner, M., Fridlind, A., Garrett, T. J., Koch, D., Menon, S., Shindell, D., Stohl, A., and Warren, S. G.: Short-lived pollutants in the Arctic: their climate impact and possible mitigation strategies, Atmos. Chem. Phys., 8, 1723-1735, doi:10.5194/acp8-1723-2008, 2008.

Quinn, P. K., Stohl, A., Arneth, A., Berntsen, T., Burkhart, J. F., Christensen, J., Flanner, M., Kupiainen, K., Lihavainen, H., Shepherd, M., Shevchenko, V., Skov, H., and Vestreng, V.: The impact of black carbon on Arctic climate, Arctic Monitoring and Assessment Programme (AMAP), Oslo, available at: http://www.amap.no/documents/ doc/the-impact-of-black-carbon-on-arctic-climate/746 (last access: 1 May 2015), 2011.

RAMR: Corporate truck fleet in Russia, Russian Avtomotive Market Research, Moscow, available at: http://www.napinfo.ru/page/ id/10180 (last access: 21 May 2016), 2012.

Rosstandard: Diesel fuel. Specifications, Federal Agency for Technical Regulation and Metrology, Moscow, available at: http: //protect.gost.ru/document.aspx?control=7\&id=185725 (last access: 24 May 2016), 2013 (in Russian).

Rosstandard: About $43 \%$ of fuesling stations, checked by Rosstandard, violate the requirements. Press-release from 1 October 2015, available at: http://gost.ru/wps/portal/pages/news, last access: 19 Novermber 2015 .

Rosstat: Construction in Russia. Statistical yearbook, Federal State Statistics Service (Rosstat), Moscow, Russia, 2014 (in Russian).

RZhD: Annual report 2012, Russian Rail Road Company, available at: http://www.e-disclosure.ru/portal/files.aspx?id=4543\&type= 2 (last access: 1 May 2016), 2013.

Sand, M., Berntsen, T. K., von Salzen, K., Flanner, M. G., Langner, J., and Victor, D. G.: Response of Arctic temperature to changes in emissions of short-lived climate forcers, Nature Clim. Change, 6, 286-289, doi:10.1038/nclimate2880, 2016.

Sarofim, M. C., DeAngelo, B. J., Grano, D., Meitiv, D. L., Alnes, L. W. H., Rive, N., Berntsen, T., Torben, K. M., Myhre, G., Bieltvedt Skeie, R., Klimont, Z., Weitz, K. A., Zapata, A., Bahner, M. A., and Zaitchik, B.: Current policies, emission trends and mitigation options for black carbon in the Arctic region. Draft working paper for the Task Force on short-lived climate forcers, Arctic Council, available at: https://oaarchive. arctic-council.org/handle/11374/955 (last access: 23 May 2016), 2009.

Subramanian, R., Winijkul, E., Bond, T. C., Thiansathit, W., Oanh, N. T. K., Paw-armart, I., and Duleep, K. G.: Climate-relevant properties of diesel particulate emissions: Results from a piggyback study in Bangkok, Thailand, Environ. Sci. Technol., 43, 4213-4218, doi:10.1021/es8032296, 2009.

Suslov, K. V.: A microgrid concept for isolated territories in Russia, 2012 IEEE Innovative Smart Grid Technologies Conference, 16 October 2012, Berlin, Germany, available at: http: //ieeexplore.ieee.org/stamp/stamp.jsp?tp=\&arnumber=6465614 (last access: 23 May 2016), 2012.

USGS: 2013 Minerals Yearbook: Russia, US Geological Survey, Washington DC, USA, 2016.

Wang, X., Westerdahl, D., Wu, Y., Pan, X., and Zhang, K. M.: Onroad emission factor distributions of individual diesel vehicles in and around Beijing, China, Atmos. Environ., 45, 503-513, doi:10.1016/j.atmosenv.2010.09.014, 2011.

Warren, S. G. and Wiscombe, W. J.: A model for the spectral albedo of snow. II: snow containing atmospheric aerosols, J. Atmos. Sci., 37, 2734-2745, 1980.

WCIOM: Development of fishery complex in Russia (in Russian), Russian Public Opinion Research Center (VCIOM), Moscow, available at: http://www.wciom.com/index.php?id=139 (last access: 23 May 2016), 2015.

WHO: Health effects of black carbon, WHO Regional Office for Europe, Copenhagen, Denmark, available at: http://www.euro. who.int/_data/assets/pdf_file/0004/162535/e96541.pdf (last access: 19 April 2015), 2012.

WHO: Health effects of particulate matter: Policy implications for countries in Eastern Europe, Caucasus and Central Asia, World Health Organization, Copenhagen, Denmark, available at: http://www.euro.who.int/_data/assets/pdf_file/0006/ 189051/Health-effects-of-particulate-matter-final-Eng.pdf (last access: 19 April 2015), 2013.

World Bank: Reducing black carbon emissions from diesel vehicles: Impacts, control strategies, and cost-benefit analysis, The World Bank, Washington D.C., USA, available at: https://openknowledge.worldbank.org/bitstream/handle/10986/ 17785/864850WP00PUBL010report002April2014.pdf (last access: 1 May 2015), 2014.

Yan, F., Winijkul, E., Jung, S., Bond, T. C., and Streets, D. G.: Global emission projections of particulate matter (PM): I. Exhaust emissions from on-road vehicles, Atmos. Environ., 45, 4830-4844, doi:10.1016/j.atmosenv.2011.06.018, 2011.

Yan, F., Winijkul, E., Streets, D. G., Lu, Z., Bond, T. C., and Zhang, Y.: Global emission projections for the transportation sector using dynamic technology modeling, Atmos. Chem. Phys., 14, 5709-5733, doi:10.5194/acp-14-5709-2014, 2014.

Zatopliaev, B. and Redko, I.: The role of small power engineering in Russia's fuel balance, Small Power Engineering, 1, 4-11, 2004.

Zvonar, A.: From modernization experience at Apatite mine, available at: http://www.slavutich-media.ru/catalog/gornaya_tehnika/ 0/iz_opita_modernizatsii_proizvodstvennih_moshchnostey.html (last access: 21 May 2016), 2010 (in Russian). 